\title{
An Archaeological Survey for Asylum Creek and No Name Creek Channel Rectification Project, Bexar County, Texas
}

Kevin J. Gross

Center for Archaeological Research

I. Waynne Cox

Center for Archaeological Research

Follow this and additional works at: https://scholarworks.sfasu.edu/ita

Part of the American Material Culture Commons, Archaeological Anthropology Commons, Environmental Studies Commons, Other American Studies Commons, Other Arts and Humanities Commons, Other History of Art, Architecture, and Archaeology Commons, and the United States History Commons

Tell us how this article helped you.

This Article is brought to you for free and open access by the Center for Regional Heritage Research at SFA ScholarWorks. It has been accepted for inclusion in Index of Texas Archaeology: Open Access Gray Literature from the Lone Star State by an authorized editor of SFA ScholarWorks. For more information, please contact cdsscholarworks@sfasu.edu. 


\section{An Archaeological Survey for Asylum Creek and No Name Creek Channel Rectification Project, Bexar County, Texas}

\section{Creative Commons License}

\section{(c) (1) (8)}

This work is licensed under a Creative Commons Attribution-NonCommercial 4.0 International License 


\title{
AN ARCHAEOLOGICAL SURVEY FOR ASYLUM CREEK AND NO NAME CREEK CHANNEL RECTIFICATION PROJECT, BEXAR COUNTY, TEXAS
}

\author{
Kevin J. Gross \\ I. Waynne Cox
}

Texas Antiquities Committee Permit No. 1147

Center for Archaeological Research The University of Texas at San Antonio ${ }^{(1)}$ Archaeological Survey Report No. 225 
The following information is provided in accordance with General Rules of Practice and Procedure Chapter 41.11 (Investigation Reports), Texas Antiquities Committee:

1. Type of investigation: Archaeological survey and monitoring at Asylum Creek and No Name Creek Channel, Bexar County, Texas.

2. Project name: Asylum Creek and No Name Creek Channel.

3. County: Bexar County, Texas.

4. Principal investigator: Jack D. Eaton

5. Name and location of sponsoring agency: San Antonio River Authority, 100 East Guenther Street, P.O. Box 830027, San Antonio, Texas 78283-0027.

6. Texas Antiquities Permit No. 1147.

7. Published by The Center for Archaeological Research, The University of Texas at San Antonio, San Antonio, Texas 78249-0658, 1993.

A list of publications by the Center for Archaeological Research can be obtained by sending $\$ 1.00$ to the Center for Archaeological Research, The University of Texas at San Antonio, San Antonio, Texas 78249-0658. 


\begin{abstract}
During August of 1992, staff archaeologists from the Center for Archaeological Research (CAR) at the University of Texas at San Antonio (UTSA) conducted surface survey, mapping, and subsurface testing adjacent to Asylum and No-Name Creeks under contract with the San Antonio River Authority in conjunction with a channel rectification project. Particular attention was given to locating cultural materials associated with the nearby San Juan Acequia. No significant cultural resources were located at either location.
\end{abstract}




\section{TABLE OF CONTENTS}

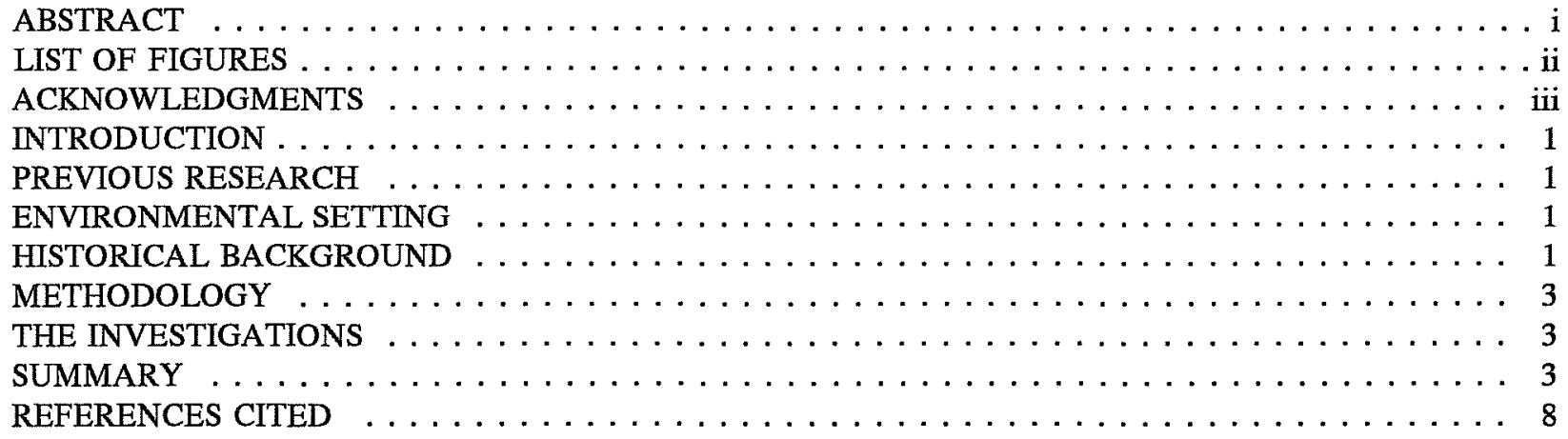

\section{LIST OF FIGURES}

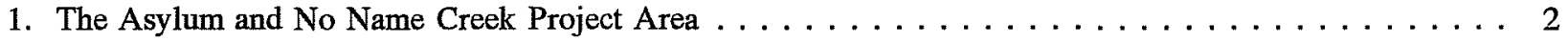

2. Property Locations, Adapted from Maverick Plat $1866 \ldots \ldots \ldots \ldots \ldots \ldots \ldots \ldots \ldots$

3. Property Location, Adapted from Dillon Plat $1879 \ldots \ldots \ldots \ldots \ldots \ldots \ldots \ldots \ldots \ldots$

4. Asylum Creek Project Area . . . . . . . . . . . . . . . . . . . . . 6

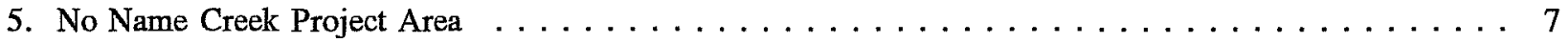




\section{ACKNOWLEDGMENTS}

The authors are grateful for the cooperation and assistance provided by the San Antonio River Authority (SARA) which supported this project. Dean Bayer, the SARA project coordinator assisted with the planning and execution of this project. Gratitude is also extended to Anne A. Fox and Guillermo I. Mendez, members of the CAR UTSA staff, who contributed to the completion of this project. 


\section{INTRODUCTION}

In August of 1992 the Center for Archaeological Research (CAR) at The University of Texas at San Antonio (UTSA) conducted a surface survey and a limited number of shovel tests at areas proposed for the Asylum and No Name Creek Channel Rectification Project. The work was completed in four working days. The field work was carried out by Kevin J. Gross, assisted by Guillermo I. Mendez, CAR-UTSA staff archaeologists. The historical background is provided by I. Waynne Cox, also of CAR staff. The work was done under contract with the San Antonio River Authority (SARA) in order to identify any cultural resources that might be affected by construction. Texas Antiquities Permit No. 1147 was issued for the project. Field notes and other information related to the project are curated at CAR-UTSA. Construction activities were documented and are in the possession of SARA. The results of the field survey, testing and monitoring are reported here.

Asylum and No Name Creeks are located in southeastern Bexar County approximately $8 \mathrm{~km}$ and $9 \mathrm{~km}$ south of downtown San Antonio, respectively (Figure 1). The San Juan Acequia runs north to south along the eastern bank of the San Antonio River and crosses both creeks. The Asylum Creek survey area is circumscribed by Pyron Road to the north, South Presa Street to the east, Southeast Military Drive to the south, and the San Antonio River to the west. The No Name Creek area is bound on the north, east, and south by the San Juan Acequia, and the San Antonio River to the west. The area is transversely bisected, north to south, by South Presa Street.

\section{PREVIOUS RESEARCH}

Numerous archaeological investigations have been conducted near the project areas. Mission San José (41 BX 3) and Mission San Juan Capistraño (41 BX 5) have been extensively examined by archaeologists and historians. Excavations at the San Juan dam (41 BX 266) were completed in 1988 (Hafernik et al. 1989). In 1976, archaeologists from the Texas Historical Commission recorded four historic sites in the immediate vicinities of the project areas (Scurlock et al. 1976). They include two late 19th-century homesteads (41 BX 258 and 41 BX 259), one 20th-century graveyard (41 BX 239), and one undated well (41 BX 240).

\section{ENVIRONMENTAL SETTING}

Both of the properties concerned are typical of the loamy bottomland sites of the San Antonio River. The soil association is Frio clay loam with a transition toward Venus clay loam on the eastern slope terrace. The soils are fertile with good moisture retention characteristics supporting a lush growth of tall grasses, brush and trees (Taylor et al. 1962:59). There are several large trees of native pecan and live oak. Woody invaders include mesquite, huisache, hackberry and condalia. The areas have flooded frequently producing a heavy growth of weedy vegetation. The flood plains around the Asylum Creek site support large areas completely covered with a heavy growth of giant ragweed (Artemisia tridentata).

\section{HISTORICAL BACKGROUND}

On March 5, 1731, the east Texas mission San José de los Nazonis was relocated to the east bank of the San Antonio River and acquired the new name of San Juan Capistraño. The acequia for the mission was probably begun about the time that the first huts were constructed on May 4,1731, but the progress on the mission, and probably its acequia, was slow during the first ten years due to frequent Apache raids, the obstructionist tactics of Governor Franquis de Lugo, and an epidemic in 1739 (Habig 1968:162). However, the acequia was in operation by February of 1740, for the first fields were reported as newly planted in the spring of that year and a report by Fray Fernández serviced the acequia was constructed along the east bank of the river, almost directly de Santa Ana comments on the "five abundant withdrawals from the river" (Santa Ana 1740). The dam which opposite the present site of Mission San Jose, and was some three hundred feet in length and projected downstream diverting the flow to the deep intake along the bank. Approximately $\mathbf{5 5 0}$ feet down the acequia a stone headgate was constructed to control the flow. The channel continued southward on the east bank of the river to the mission slightly over three miles. The acequia followed a natural contour on the terrace of the bank, encountering difficulty at two points along its route, the two creeks which crossed its path, now known as Asylum and No Name Creeks. In February of 1833, Angel Navarro appealed to the Mexican government for a tract of land "for the raising of cattle and for agricultural purposes". Upon approval of his request he selected a tract, "near the Rosillo" (Bexar County Deed Records [BCDR], Office of the County Clerk, Deed Records Office, Heritage Plaza Building, San Antonio. The land 


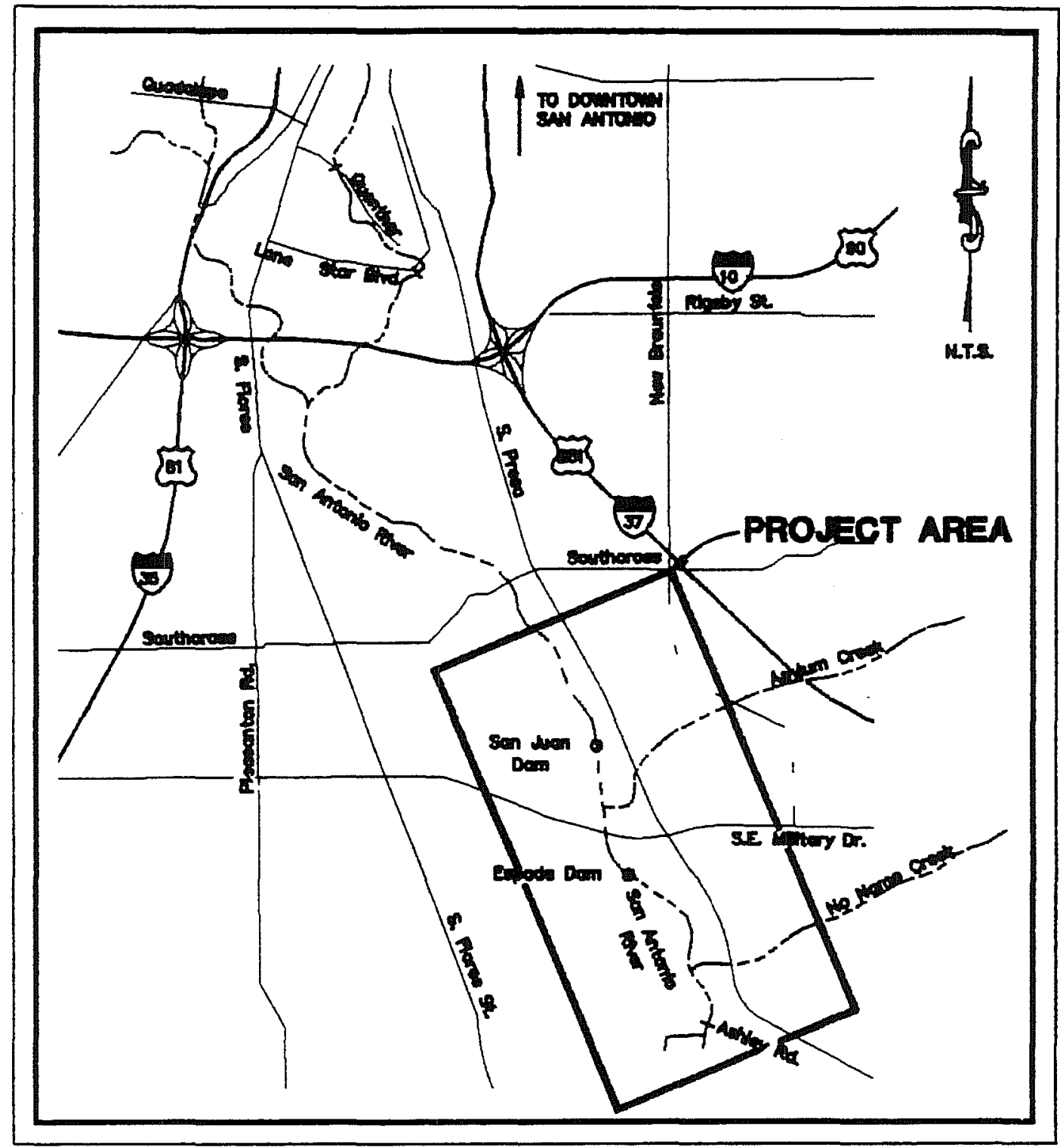

Figure 1. The Asylum and No Name Creek project area. 
selected was that from the dam south between the river and the acequia. In 1866, the heir of Angel Navarro, Juan de Zambrano and Federico Navarro, transferred "that tract or parcel of land...known as the Rancho Tulillo, lying opposite to the San José Mission land and between the San Antonio River and the sequia (sic) of San Juan" to Samuel A. Maverick for $\$ 1800$ (BCDR U2:4-5) (Figure 2). The property remained in the Maverick family, and in 1943, was in question in a suit between Robert Maverick, et al. vs. Lewis Maverick, Jr. et al (Bexar County Probate Records, County Clerk's Office and District Court Records, Bexar County Courthouse, San Antonio, Case F-1830). The receiver of the case, A. A. Altgelt, sold 16.3 acres of the property to Charles W. and Lasca Franklin Neal in January of 1944 (BCDR 2011:502). They transferred the property to Mollie Alexander, a widow, in June of 1951 (BCDR 3011:155).

The tract to the south where No Name Creek intersects the acequia was acquired from the Mexican government by Jose Maria Ramires, who sold the property to Henry Miller and John Storm, March 20, 1854 (BCDR L2:507). The following year Miller transferred the property to Edward Miles, who in turn sold it to Charles L. Leges and Samuel Hall (BCDR G2:225, N2:108). They then conveyed the tract to Mary Rossman (BCDR N2:225). In March of 1878, Mathew and Mary Rossman sold twenty acres to Jane Dillon, wife of Arther Dillon for $\$ 800$ (BCDR U2:393). A survey plat of the property performed June 12, 1879 for Dillon indicated that the property is fenced just to the north of the creek intersection with the acequia and the Dillon home is the only structure on the property, located to the southwest corner of the property (BCDR 11:461) (Figure 3).

There is nothing in the historical data nor the deed records that indicate that the areas under investigation ever contained structures or improvements other than that of the existing acequia. While the path of the acequia has varied over the years, it appears from existing data to remain essentially in the same area as at the time of its initial construction.

\section{METHODOLOGY}

The areas adjacent to Asylum and No Name Creeks, including the bank of the San Juan Acequia, were subjected to a pedestrian survey by two archaeologists at variable intervals. Both properties were marked by dense vegetation and poor surface visibility; therefore, particular attention was directed to areas with fair, or better, surface visibility. Ten locations were selected for shovel testing near Asylum Creek. Six subsurface shovel tests were made near No Name Creek. No significant cultural resources were found in the tests. The location of each test was recorded by tape and compass measurements. Distance and depth were recorded in metric units.

\section{THE INVESTIGATIONS}

Three light lithic scatters were identified on the eastern bank of Asylum Creek (Figure 4). The scatters consisted of tested cobbles, primary flakes, secondary flakes, and small chips. Shovel tests revealed that there were no subsurface deposits. There were only two isolated primary flakes observed on the surface of the west bank. Testing indicated no subsurface archaeological remains. One light lithic scatter, containing one core and five tertiary flakes, was recognized at the No Name Creek area (Figure 5). A shovel test (ST 2) yielded thirteen core fragments, seven primary flakes, two secondary flakes, and two tertiary flakes from $5-30 \mathrm{~cm}$ beneath the surface. No other cultural materials were identified in that project area.

\section{SUMMARY}

As a result of the survey and testing, no significant prehistoric or historic resources were identified other than the route of the San Juan Acequia. The tendency for the creeks to flood frequently and the shallow depth at which materials were recovered suggests that the lithic scatters associated with Asylum Creek and No Name Creeks are most likely secondary deposits. Due to the complete destruction of the area, no further action is recommended. 


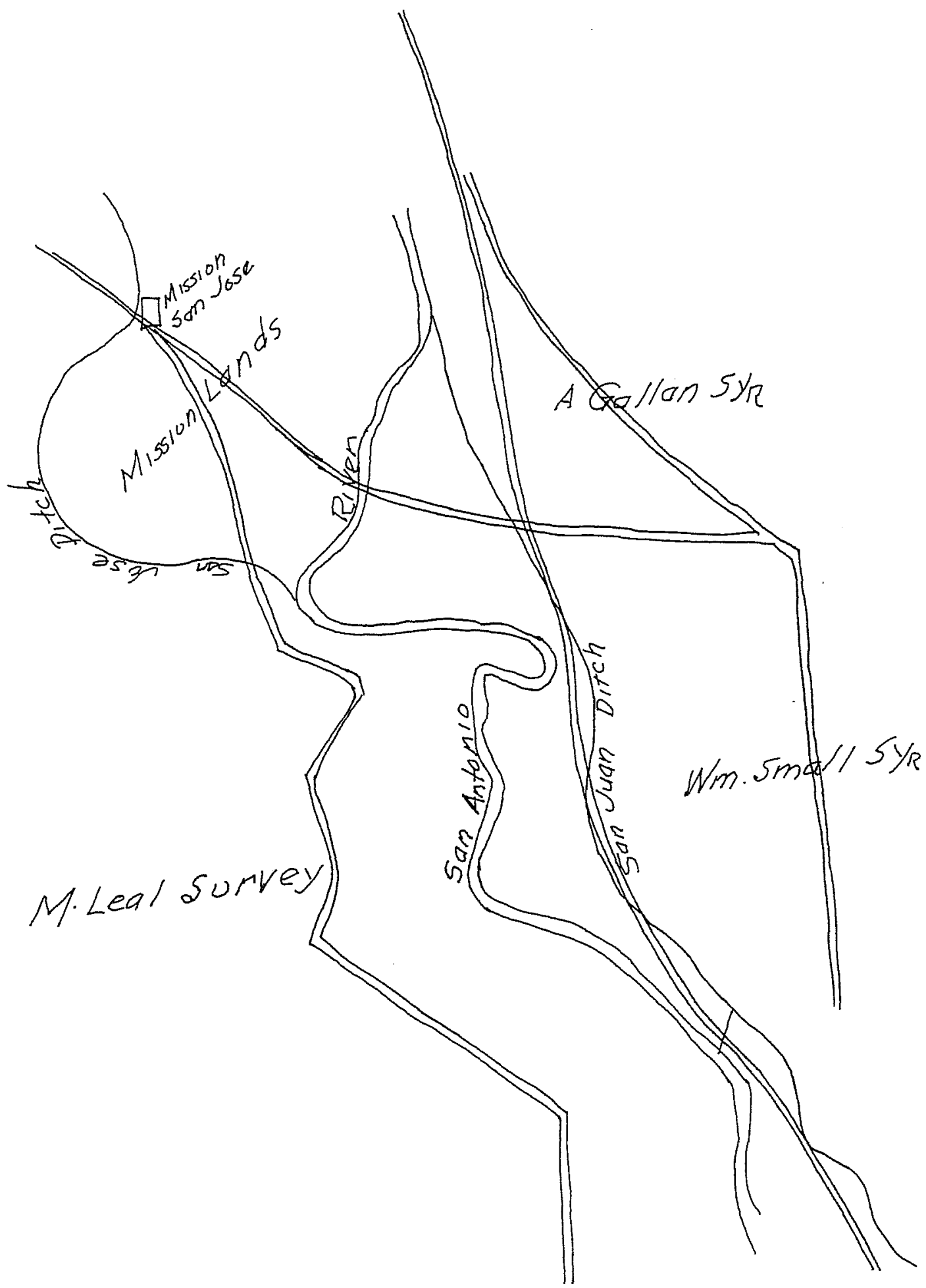

Figure 2. Property locations, adapted from Maverick plat 1866. 


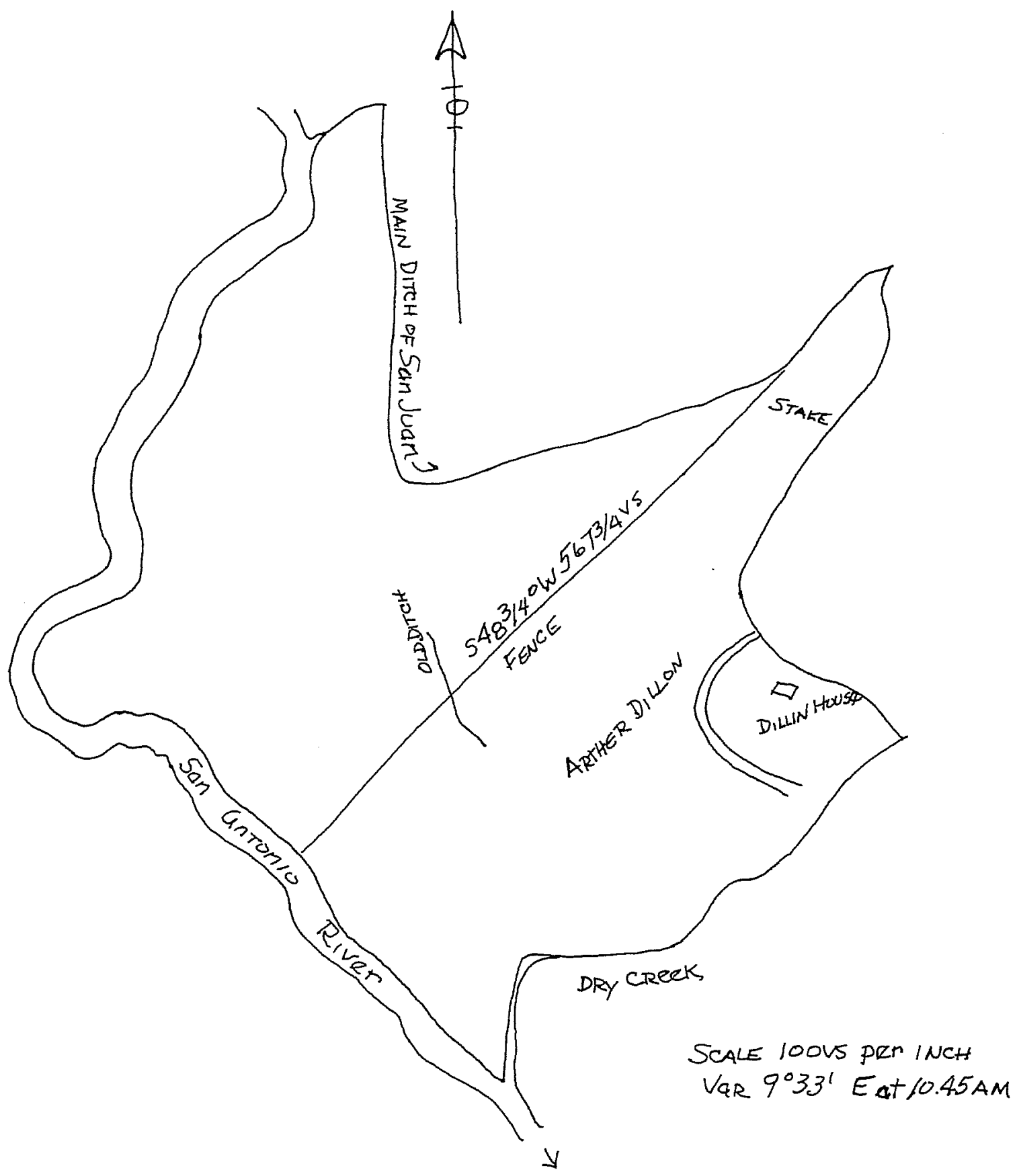

Figure 3. Property location, adapted from Dillon plat 1879. 


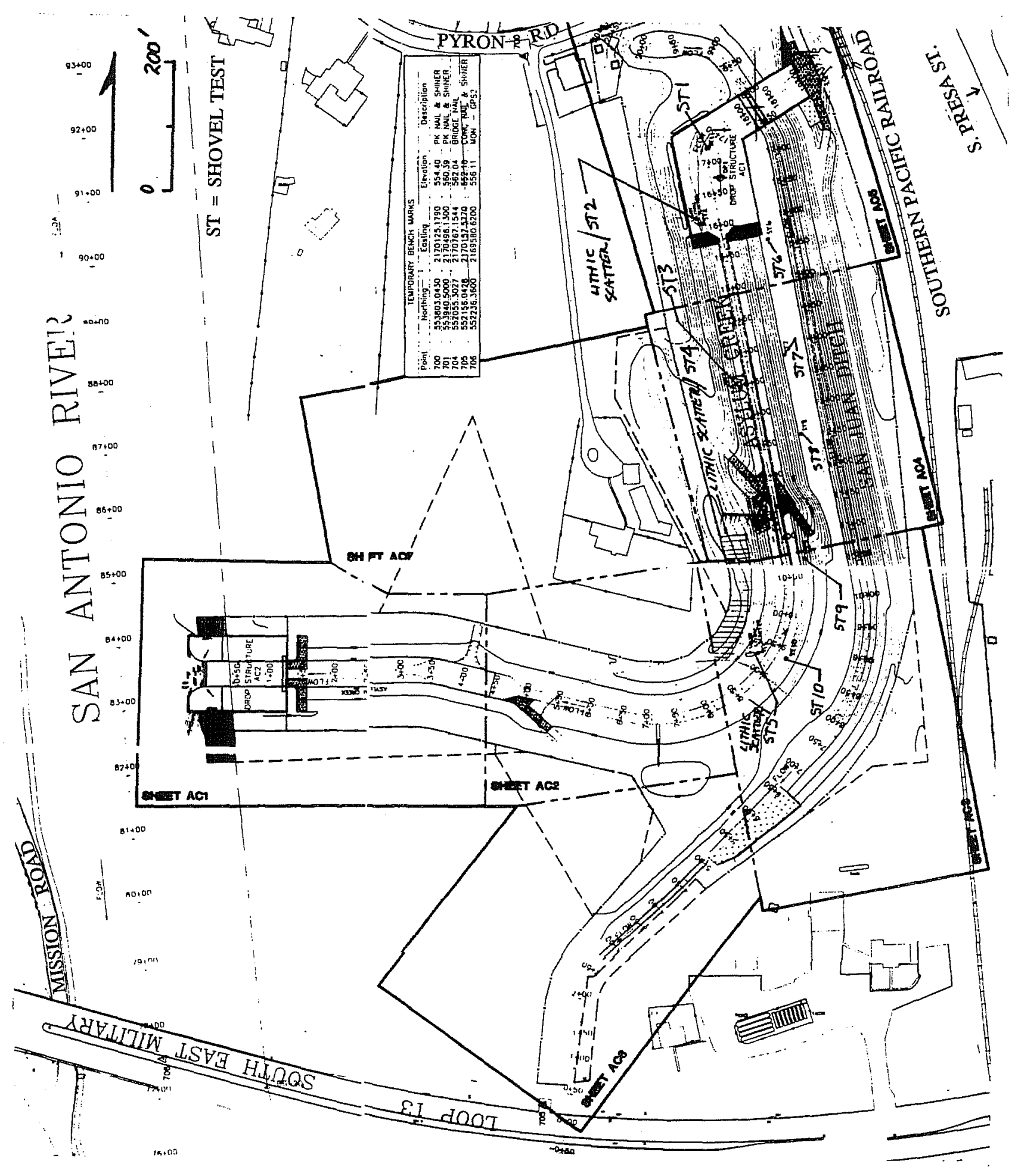

Figure 4. Asylum Creek project area. 


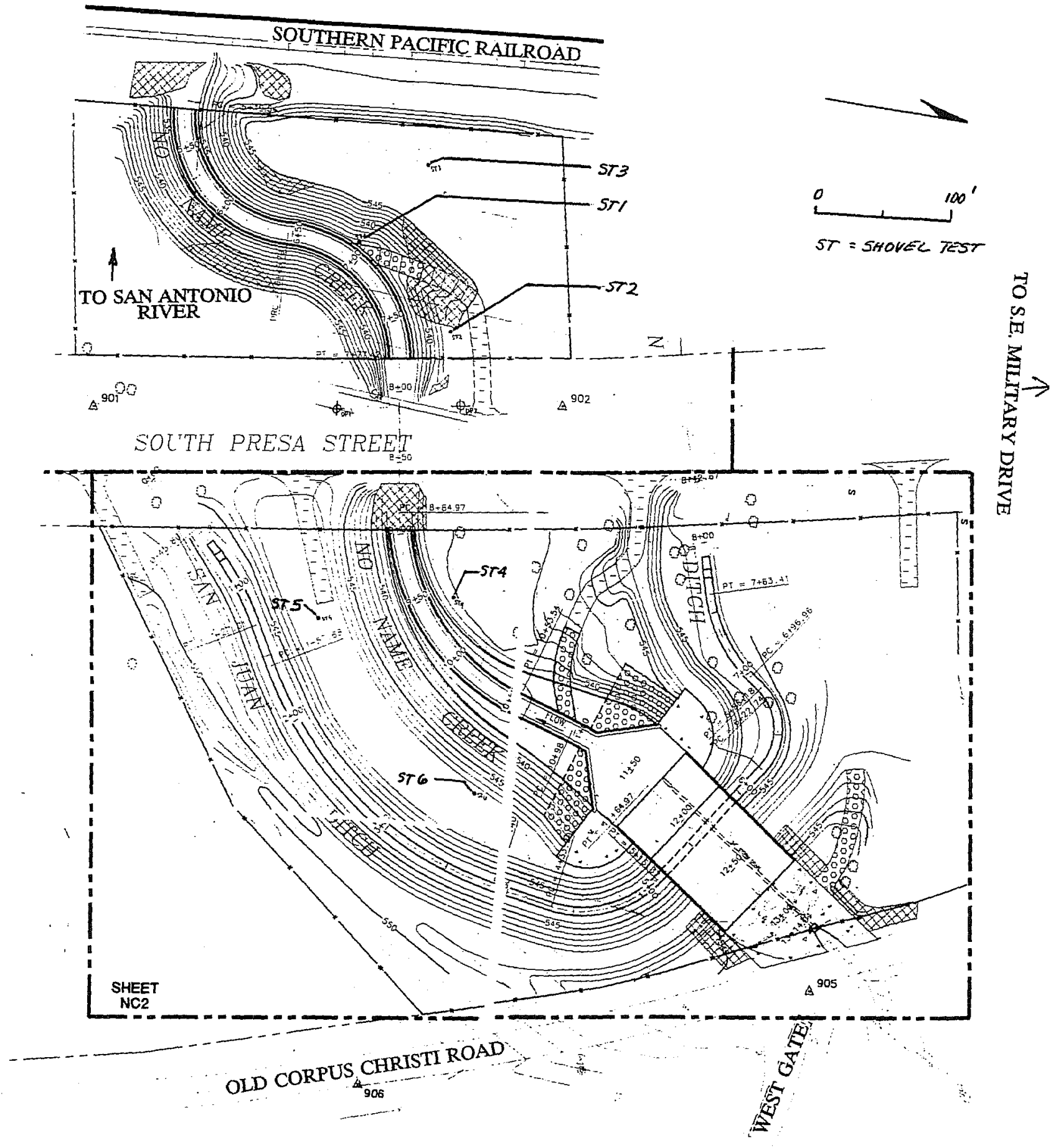

Figure 5. No Name Creek project area. 


\section{REFERENCES CITED}

Habig, M. A.

1968 The Alamo Chain of Missions: A History of San Antonio's Five Old Missions. Franciscan Herald Press, Chicago.

Hafernik, D., I. W. Cox, and A. Fox

1989 Archaeological Investigation of the San Juan Dam, 41 BX 266, Bexar County, Texas.Archaeological Survey Report, No. 179, Center for Archaeological Research, The University of Texas at San Antonio.

Santa Ana, Fr. B. F. de

1740 Fr. Benito Fernández de Santa Ana to Fr. Pedro del Barco, February 20. Translated, by Fr. B. Leutenegger. The Americas, 25(2):199-206, 1968.

Scurlock, D., A. Benavides, D. Isham, and J. Clark

1976 An Archaeological and Historical Survey of the Proposed Mission Parkway, San Antonio, Texas. Office of the State Archeologist, Texas Historical Commission, Archeological Survey Report 17, Austin.

Taylor, F.B., R. B. Hailey and D.L. Richmond

1962 Soil Survey of Bexar County, Texas. United States Department of Agriculture, Soil Conservation Service, 1962. 


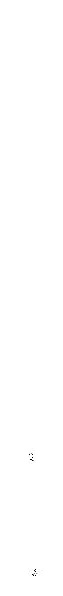



